\title{
Studies on the application of human and cattle urine on soil properties and yield of vegetable crops
}

\section{H. YOGEESHAPPA, C.A. SRINIVASAMURTHY AND D. KRISHNAMURTHY}

MEMBERS OF RESEARCH FORUM:

Corresponding author : H. YOGEESHAPPA, Department of Soil Science and Agricultural Chemistry, College of Horticulture (U.H.S.), Munirabad, KOPPAL (KARNATAKA) INDIA

Email: yogeeshappa@gmail.com

\section{Co-authors :}

C.A. SRINIVASAMURTHY, Department of Soil Science and Agricultural Chemistry, College of Agriculture, University of Agricultural Sciences, G.K.V.K., BENGALURU (KARNATAKA) INDIA

D. KRISHNAMURTHY, Department of Agronomy, College of Agriculture, University of Agricultural Sciences, RAICHUR (KARNATAKA) INDIA

Received : 12.02.2016; Revised : 18.03.2016; Accepted : 14.04.2016

\section{Summary}

The field experiment was conducted at farmer's field with the application of human and cattle urine as liquid fertilizer or nutrient sources on ashgourd [Benincasa hispida (Thunb.) Cong.], French bean (Phaseolus vulgaris L.), pole bean (Phaseolus vulgaris L.) and pumpkin (Cucurbita maxima) as test crops at Nagasandra village, Doddaballapur, Bangalore rural district from 2009 to 2011. The objective of the study was to know the effect of repeated application of human urine and cattle urine on soil properties and yield of vegetable crops. Application of recommended dose of nitrogen through human urine in three split doses plus gypsum recorded higher yield $\left(39.2,14.2,17.4\right.$ and $38.7 \mathrm{tha}^{-1}$, for ashgourd, French bean, pole bean and pumpkin, respectively) and it was at par with recommended dose of nitrogen through cattle urine in three splits plus gypsum $\left(\mathrm{T}_{14}: 38.0,14.1,16.6\right.$ and $37.5 \mathrm{t} \mathrm{ha}^{-1}$, for ashgourd, French bean, pole bean and pumpkin, respectively) and recommended dose of fertilizers ( $T_{2}$ : $36.7,13.7,15.8$ and $36.8 \mathrm{tha}^{-1}$, for ashgourd, French bean, pole bean and pumpkin, respectively). Significantly higher primary, secondary and micronutrient content in soil were recorded with recommended dose of nitrogen through human urine in three split doses plus gypsum at harvest of ashgourd crop. The trend of variation in available nitrogen, phosphorus and potassium content of soil recorded at harvest of ashgourd was retained in subsequent seasons when French bean, pole bean and pumpkin crops were grown in sequence after ashgourd crop in the same plots receiving same treatments.

Key words : Ashgourd, Pole bean, Human urine, Cattle urine, Nitrogen, Nutrients

How to cite this article : Yogeeshappa, H., Srinivasamurthy, C.A. and Krishnamurthy, D. (2016). Studies on the application of human and cattle urine on soil properties and yield of vegetable crops. Asian J. Soil Sci., 11 (1) : 29-36 : DOI : 10.15740/HAS/AJSS/11.1/29-36. 